\title{
The Analysis of Mathematics Teacher Ability in Applying the RME Approach in Jambi City through Lesson Plan Analysis
}

\author{
Isna Yuliastuti \\ ${ }^{1}$ Mathematic Education Department, Postgraduate, Universitas Jambi- Indonesia \\ Email: isnayuliastuti17@gmail.com
}

\author{
Kamid \\ ${ }^{2}$ Mathematic Education Department, Education and Teacher Training Faculty, Universitas Jambi-Indonesia. \\ Email: mas_gaya@yahoo.com \\ Maison \\ ${ }^{3}$ Science-Physic Education Department, Education and Teacher Training Faculty, Universitas Jambi-Indonesia \\ Email: maison@unja.ac.id
}

DOI: $10.31364 /$ SCIRJ/v8.i12.2020.P1220825

http://dx.doi.org/10.31364/SCIRJ/v8.i12.2020.P1220825

\begin{abstract}
This study aims to determine the ability of junior high school mathematics teachers to apply the RMA approach in Jambi City. This research is a descriptive analysis research, which seeks to describe the ability of teachers in planning learning approaches to Realistic Mathematics Learning. The sample used in the study was 40 junior high school teachers taken randomly in Jambi City. Of the total 40 samples consisting of 25 teachers from public schools (one school 1 teacher) and 15 teachers from private schools were randomly drawn. Data collection is done by means of document analysis in the form of a learning plan that has been developed by the teacher concerned. RPP Analysis focuses on the Realistic Mathematics Learning approach (concepts, steps, and experience applying them). The results showed that the ability of teachers in general (in the category is still relatively "low" which is as much as $45 \%$. Then followed by teachers with abilities in the category of "moderate" as much as $32.5 \%$. As for teachers with good abilities in developing RPP based The RMA is $22.5 \%$ and the achievement of the average score in the analyzed component is known that the exercise/evaluation questions component is the hardest part felt by the teacher in implementing RMA learning with an average score of 2 (low). The easiest is the use of media/tools used by obtaining an average score of 3 (moderate) and components of the steps of learning by obtaining an average score of 2.6 (moderate).
\end{abstract}

Keyword: Mathematics Teacher's Ability, RMA, Lesson plan

\section{INTRODUCTION}

One of the goals of learning mathematics according to the Indonesia National Education Standards Agency is that students have the ability to solve problems that include the ability to understand problems, design mathematical models, solve models and interpret the solutions obtained. These goals place problem-solving into an important part of the mathematics curriculum. Based on the results of learning mathematics, the curriculum in learning mathematics should include three things, namely: concepts, skills, and problemsolving. According to Areerachakul (2015) and Handayani (2015) mathematics learning is one component of basic education in the fields of teaching.

Lander \& Brown (1995), Strayer (2012) and Navilarekallu (2020) argues that in interactions in the classroom, teachers must give a lot of freedom to students, to be able to investigate themselves observing themselves, studying alone and looking for solutions to their own problems. Learning mathematics itself is a process of a student to understand and understand mathematics. In learning mathematics there must be a link between students' previous learning experiences and concepts to be taught. This is in accordance with the "spiral learning" as a consequence of Mattingly, Lutkehaus, \& Throop (2008), Vidal, Bruna, Giryes, \& Soatto (2017) and Lample \& Charton (2019) proposition.

Mathematics learning is a process or activity of mathematics teachers in doing mathematics to their students, which contains the efforts of teachers to create a climate and service to the abilities, potentials, interests, talents and needs of diverse students so that optimal interaction occurs between teachers and students and between students with students in learning mathematics (Milaturrahmah, Mardiyana, \& Pramudya, 2017). A professional teachers are needed to carry out learning successfully (Borba et al., 2016).

Tarigan (2012), Bujak et al., (2013) and Ibáñez \& Delgado-Kloos, (2018) that, "Mathematics is related to reality, is close to the world of children, and is relevant to society", so mathematics is not learned as a closed system, but rather as an activity or referred to as mathematical mathematics. Mathematics as a human activity is a problemsolving activity, problem finding, but also the activity of organizing a system. Thus according to him realistic mathematics learning is an approach aimed at developing a 
practical, logical, critical, and honest mindset with orientation to mathematical reasoning in solving problems". Learning with a realistic mathematical approach is very important (Wibowo, 2017) and has been widely applied in various developed countries, for example the United Kingdom and the United States (Bommarito \& Katz, 2010).

Bonotto (2010), Wardono, at., al., (2016), Ulandari, at al., (2019) explained that Realistic Mathematics learning is basically the use of reality and environment that students have understood to facilitate the learning process of mathematics, with the hope that the goals of mathematics learning can be achieved better than in the past. What is meant by reality are tangible or concrete things, which can be observed or understood by students through imagining? Whereas what is meant by environment is the environment in which students are located, whether the school, family or community can be understood by students.

Realistic mathematics learning is basically the use of reality and the environment experienced by students to expedite the process of learning mathematics, so as to achieve the goals of mathematics education better than the past (Lestari \& Surya, 2017), (Wardono et al., 2016) and (Makonye, 2014). The process of learning realistic mathematics uses contextual problems as a starting point in learning mathematics (Bray \& Tangney, 2016). The Realistic Mathematics Education (RME) approach is a mathematics learning approach that involves students' realities and experiences (Chisara, Hakim, \& Kartika, 2018).

According to Widada, et al., (2019), Laurens, et al., (2018), and Prastiti, (2009) the characteristics of the RME approach include: 1) phenomenological exploration or use context; 2) use models or bridging by vertical instruments; 3 ) the use of student own production and construction of student contributions; 4) the interactive character of the teaching process or interactivity; and 5) intertwining or various learning strands. These characteristics are expected to emerge in the learning process so that students' connection and communication skills can increase.

Realistic mathematical learning approaches are believed to be able to increase students' understanding of mathematical concepts. According to Prastiti, (2009) implementation of Realistic Mathematics Education can improve communication skills and solving junior high school mathematics problems. Implementation of realistic mathematics education (PMR) to improve mathematic thinking ability and learning independence of students (Muhtadi \& Sukirwan, 2018). In addition, research also proves that the implementation of the RMA learning model can improve the ability of students to construct knowledge with their own abilities through the activities they carry out in teaching and learning activities that are associated with reality as part of human activities (Hafni \& Iskandar, 2017).

Susilowati (2018) said that by applying RMA student activities and student mathematics learning outcomes by applying the Realistic Mathematic Education (RME) learning model. Rahman (2017), Astuti, (2018) also said that the application of realistic mathematic education (RME) approach to statistics materials to improve concept understanding and achievement. Furthermore, research conducted by Widyastuti and Pujiastuti, (2014) provides results that students who are taught with Realistic Mathematics Education produce higher Mathematical Problem-Solving abilities than students who are taught with ordinary learning. Afriansyah (2016) concluded that the Indonesian Realistic Mathematics Learning (PMRI) approach had an effect on students' mathematical problemsolving abilities.

In addition, the Realistic Mathematics Learning Approach is also in line with the 2013 curriculum which emphasizes the scientific activities of the main 5M activities, namely observing, asking questions, collecting data, associating and connecting. Thus the implementation of the Realistic Mathematics Learning approach will precisely strengthen the implementation of the curriculum. Therefore the Realistic Mathematics Learning approach should be able to be applied well and massively by mathematics teachers, especially at the junior high school level.

Based on preliminary observations on a number of junior high schools in the city of Jambi, data were obtained that the Realistic Mathematics Learning approach had not been applied by the teacher. Several models and approaches that have been implemented in some of these schools include drill learning models, scientific learning approaches, inquiry approaches, problem-based learning approaches. The learning approach to Realistic Mathematics Learning has not been applied.

With the Realistic Mathematics Learning approach in the Jambi City Junior High School not being well and massively implemented, the merits of the model have not been felt much. If according to some of the above research results, the application of the Realistic Mathematics Learning approach will bring a positive impact on student learning outcomes, both in the cognitive, psychomotor and affective domains. Therefore, it is necessary to find an answer to the question why do Mathematics teachers in Jambi City have not optimally applied the Realistic Mathematics Learning approach in schools? What are the obstacles of mathematics teachers in applying the Realistic Mathematics Learning approach? And how is the ability of mathematics teachers in applying the Realistic Mathematics Learning approach?

Referring to the description and above, the focus of this research is to find out the answer to the question of how is the ability of mathematics teachers in applying the Realistic Mathematics Learning Approach? This ability will be seen based on the learning plan that has been developed by the teacher. This is in line with the explanation by Green (2016) and Fujii (2016) that the function of this lesson plan is as a reference for teachers to carry out teaching and learning activities (learning activities) to be more directed and run effectively. Nesari \& Heidari (2014) also said that written lesson plans can encourage the creation of effective learning and learning achievement.

Nasution (2014) said that the learning plan is a written description in the learning process that shows what, when, where and with what a learning process will be carried out and how students will be assessed. Therefore Harrow College (2019) said that the learning plan is the key to successful 
learning. According to Beinart (2004), Rashad \& Abdulsafi (2019) and Nida (2019) states that learning plans can help teachers reduce negative student behavior while learning and improve student learning outcomes. By analyzing the learning plan it will be known how the teacher's ability to plan learning approaches to Realistic Mathematics Learning. This can be understood because the learning plan will include a model/approach that will be carried out by the teacher during the learning process.

\section{II.RESEARCH METHODS}

This research is a descriptive analysis research, which seeks to describe the ability of teachers in planning learning approaches to Realistic Mathematics Learning. The sample used in the study was 40 junior high school teachers taken randomly in Jambi City. Of the total 40 samples consisting of 25 teachers from public schools (one school 1 teacher) and 15 teachers from private schools were randomly drawn. Data collection is done by means of document analysis in the form of a learning plan that has been developed by the teacher concerned. The RPP analysis focuses on the Realistic Mathematics Learning approach (concepts, steps, and experiences applying it). The data analysis was carried out using techniques according to Miles \& Huberman (2012) and Ridder, et al., (2014) which included analysis activities consisting of three activities that occurred simultaneously, namely data reduction, data presentation, and drawing conclusions/verification.

As has been explained above that the learning of realistic mathematics is basically the use of reality and the environment with a realistic mathematics learning process using contextual problems as a starting point in learning mathematics. Thus the situation is reflected in the learning steps, the media used and the practice/evaluation questions developed by the teacher. Therefore the RPP analysis is focused on this issue. RPP assessment is done with the help of assessment rubric. Each component has a maximum score of 5 points and a minimum score of 1 point. Thus the maximum total score achieved by all teachers is 200 points and the minimum score is 40 points.

Based on the scores obtained, then the data is presented in percentages based on the learning implementation of the Realistic Mathematics Learning approach. The categorization of teacher abilities is presented in the form of "low", "medium", and "high" categories based on the RPP assessment rubric that has been developed.

\section{DATA AND DISCUSSION}

Based on the analysis of the three components of the mathematics teacher lesson plan in Jambi City, the following data are obtained:
Table 1. Percentage of Teacher Capability Categories

\begin{tabular}{lllll}
\hline No & $\begin{array}{c}\text { Value } \\
\text { Range }\end{array}$ & $\begin{array}{l}\text { Number } \\
\text { of } \\
\text { Teachers }\end{array}$ & $\begin{array}{l}\text { Percentage } \\
(\%)\end{array}$ & Category \\
\hline 1 & $11-15$ & 9 & 22,5 & High \\
2 & $6-10$ & 13 & 32,5 & Moderate \\
3 & $1-5$ & 18 & 45 & Low \\
\hline & Total & 40 & $100 \%$ & \\
\hline
\end{tabular}

Referring to the data in Table 1, it can be understood that based on the results of the RPP analysis it is found that the ability of teachers in general (in the category of relatively "low" is as much as $45 \%$. Then followed by teachers with abilities in the category of "medium" as many as 32.5 The teacher with good ability in developing RMA-based RPP is $22.5 \%$, therefore this shows that in general the learning of RMA-based mathematics in Jambi City has not been optimally carried out by mathematics teachers. The above data can be understood through Figure 1 the following:

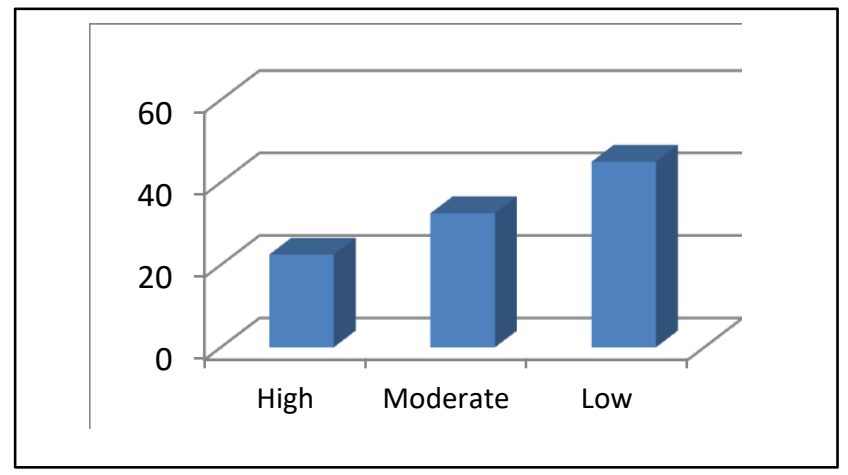

Figure 1. Percentage of Teacher Capability Categories

More in-depth analysis is related to the lesson plan components that have been developed by the teacher, namely the components of the learning steps, the media/tools used as well as evaluation questions or practice questions in learning Table 2. Achievements of Average scores in the Analysis component

\begin{tabular}{lllll}
\hline No & $\begin{array}{l}\text { Component } \\
\text { Analysis }\end{array}$ & Total & Average & Category \\
\hline 1 & Learning steps & 105 & 2,62 & Moderate \\
2 & Media/Tools used & 120 & 3 & Moderate \\
3 & Practice/ assessment & 80 & 2 & Low \\
& questions & 305 & 2,5 & Moderate \\
\hline & Average & 305 &
\end{tabular}

Referring to Table 2, namely the achievement of the average score on the components analyzed it is known that the component of exercise/evaluation questions is the hardest part felt by the teacher in implementing RMA learning with an average score of 2 (low). The easiest component is the use of media/tools used by obtaining an average score of 3 (moderate) and the components of the steps of learning by 
obtaining an average score of 2.6 (moderate). These results can be seen in Figure 2 below:

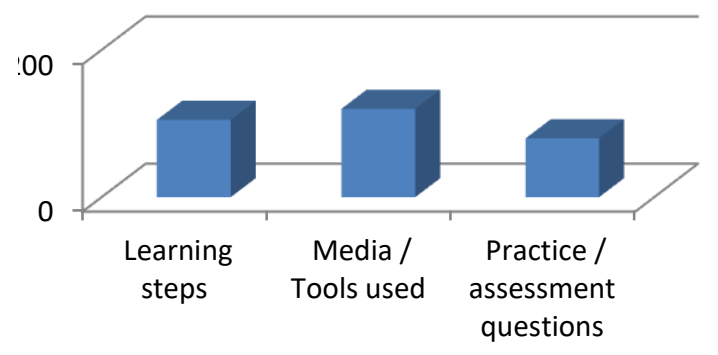

Figure 2. Teacher's Ability in Compound Analysis

Referring to the description of the data above, it can be understood that in general RMA-based mathematics learning in Jambi City has not been optimally implemented by mathematics teachers. The exercise/evaluation questions component is the most difficult part felt by teachers in implementing RMA learning with an average score of 2 (low). This finding is in line with research conducted by Juniriang (2016) that the factors that were least considered by teachers were evaluation of learning (60\%), media and facilities (60\%). Thus it should be suspected that the lack of optimal learning of RMA in schools is caused by these two components, namely: media/learning tools and practice/evaluation questions.

In addition, the above findings also show that in general mathematics teachers at the junior high school level in Jambi City still have difficulty in implementing contextual learning by utilizing reality and the environment as learning resources. This is as explained by Soedjadi (2014) and Van den \& Drijvers (2014) that realistic mathematics learning is basically the use of reality and the environment understood by students to facilitate the process of learning mathematics. Zakaria \& Syamaun (2017), Iis Holisin (2007), Wijaya (2012) also mentioned that teachers must associate mathematical concepts with students' experiences in daily life and re-apply mathematical concepts that students have in their daily lives.

According to D. Tarigan \& Sinaga (2015), the RME learning model has 5 characteristics, namely (1) the use of contextual problems, (2) the use of vertical instruments, (3) the presence of student contributions, (4) interactive activities, (5) the existence of topic related in learning. Meanwhile, according to Afriansyah (2016), (Hidayat \& Iksan, 2015), the process of learning mathematics with the RME learning model can be done with the steps: (1) understanding contextual problems; (2) solving contextual problems; (3) comparing and discussing answers; and (4) gathering answers. Thus during the implementation of learning to meet the elements or characters above can already be said as learning with the RMA approach.

Referring to the opinion of Oftiana \& Saefudin (2017) that the Indonesian Realistic Mathematics Learning (PMRI) approach has an effect on students' mathematical problemsolving abilities. As it is known that the ability to solve problems is one of the abilities that are very important for students. Boyatzis \& Boyatzis (2008), Partners for 21st Century Skills, (2006) and Wismath (2013) states that one of the important components of 21 st-century education is problem-solving ability. In addition Burkholder et al., 2020) also mentioned that problem-solving ability is the mandate of the $21^{\text {st }}$ century skill Thus, RMA as one of the learning approaches that has been proven to be able to improve problem-solving abilities and in line with Indonesia's national curriculum needs to be mastered by teachers. Therefore, the teacher's lack of ability to plan learning using the RMA approach needs serious attention.

The success of the implementation of learning is determined by the maturity of learning planning. Good and mature learning planning will guarantee the successful implementation of learning in the classroom. This is in line with the explanation of Kunandar (2015) that the function of this learning plan is as a reference for teachers to carry out teaching and learning activities to be more directed and run effectively. Sufiati \& Afifah, (2019),Ragbir-Shripat \& Mohan (2019) and Vaccari, Farias, \& Porto, (2020) also said that a written learning plan can encourage the creation of effective learning. Therefore, to implement quality RMA learning, teachers must prepare a mature learning plan. The learning plan must refer to the characteristics of the RMA and the main components of the lesson plan, namely, the steps of learning, the media/tools used and the questions of practice/evaluation.

\section{CONCLUSIONS AND RECOMMENDATIONS}

Referring to the data and discussion above, the results of the RPP analysis found that the ability of teachers in general (in the category is still relatively "low" as much as $45 \%$. Then followed by teachers with abilities in the category of "medium" as many as $32.5 \%$. As for teachers with good skills in developing RMA-based RPP as much as $22.5 \%$, the achievement of the average score on the components analyzed is known that the exercise/evaluation questions component is the hardest part felt by teachers in implementing RMA learning with an average score of 2 (low) The easiest component is the use of media/equipment used by obtaining an average score of 3 (moderate) and the components of the steps of learning by obtaining an average score of 2.62 (moderate).

Based on the results of the research as described above, at the end of this study some recommendations must be given, namely: (1) mathematics teachers in Jambi City Junior High Schools need to be trained massively and systematically to plan and implement and evaluate the implementation of learning with realistic mathematical approaches, (2) the need for targeted and continuous assistance for teachers so that they are gradually able to implement RMA professionally.

\section{ACKNOWLEDGMENT}


This research has involved many parties, from planning, implementing to writing reports and publications. For this reason, the researcher would like to thank all research subjects, namely the principal, vice principal, staff who have helped provide information/data so that the research can be completed. The researcher also expressed his special gratitude to the Principal of SMP Negeri 17 Kota Jambi who had given permission and supported this research.

\section{References}

Afriansyah, E. A. (2016). Makna Realistic dalam RME dan PMRI. Lemma.

Areerachakul, S. (2015). Using Electronic Medias for Science Mathematic and English in School under Office of the Basic Education Commission, Thailand. Procedia - Social and Behavioral Sciences. https://doi.org/10.1016/j.sbspro.2015.07.110

Astuti, A. (2018). Penerapan Realistic Mathematic Education (Rme) Meningkatkan Hasil Belajar Matematika Siswa Kelas VI SD. Jurnal Cendekia : Jurnal Pendidikan Matematika. https://doi.org/10.31004/cendekia.v2i1.32

Beinart, P. (2004). Lesson plan. New Republic. https://doi.org/10.1016/b978-1-84334-592-3.50003-3

Bommarito, M. J., \& Katz, D. M. (2010). A mathematical approach to the study of the United States Code. Physica A: Statistical Mechanics and Its Applications. https://doi.org/10.1016/j.physa.2010.05.057

Bonotto, C. (2010). Realistic mathematical modeling and problem posing. In Modeling Students' Mathematical Modeling Competencies: ICTMA 13. https://doi.org/10.1007/978-1-4419-0561-1_34

Borba, M. C., Askar, P., Engelbrecht, J., Gadanidis, G., Llinares, S., \& Aguilar, M. S. (2016). Blended learning, elearning and mobile learning in mathematics education. ZDM - Mathematics Education. https://doi.org/10.1007/s11858-016-0798-4

Boyatzis, R., \& Boyatzis, R. E. (2008). Competencies in the 21st century. Journal of Management Development. https://doi.org/10.1108/02621710810840730

Bray, A., \& Tangney, B. (2016). Enhancing student engagement through the affordances of mobile technology: a 21 st century learning perspective on Realistic Mathematics Education. Mathematics Education Research Journal. https://doi.org/10.1007/s13394-015-0158-7

Bujak, K. R., Radu, I., Catrambone, R., MacIntyre, B., Zheng, R., \& Golubski, G. (2013). A psychological perspective on augmented reality in the mathematics classroom. Computers and Education. https://doi.org/10.1016/j.compedu.2013.02.017

Burkholder, E. W., Miles, J. K., Layden, T. J., Wang, K. D., Fritz, A. V., \& Wieman, C. E. (2020). Template for teaching and assessment of problem solving in introductory physics. Physical Review Physics Education Research. https://doi.org/10.1103/physrevphyseducres.16.010123
Chisara, C., Hakim, D. L., \& Kartika, H. (2018). Implementasi Pendekatan Realistic Mathematics Education (RME) dalam Pembelajaran Matematika. Journal Homepage.

Fujii, T. (2016). Designing and adapting tasks in lesson planning: a critical process of Lesson Study. ZDM Mathematics Education. https://doi.org/10.1007/s11858016-0770-3

Green, R. (2016). Lesson plan. New Design. https://doi.org/10.4324/9780429487101-6

Hafni, R., \& Iskandar, D. (2017). Implementasi Model Pembelajaran Rme Dalam Menyelesaikan Model Matematikasebagai Gambaran Aplikasi Ekonomi ( Studi Kasus Mahasiswa Semester I Mata Kuliah MatematikaEkonomi Program Studi Manajemen Fakultas Ekonomi UMSU ). Universitas Muhammadiyah Sumatera Utara (UMSU).

Handayani, A. D. (2015). Mathematical Habits of Mind : Urgensi dan Penerapannya dalam Pembelajaran Matematika. Jurnal Math Educator Nusantara.

Harrow College. (2019). Example of a Good Lesson Plan. Harrow College.

Hidayat, R., \& Iksan, Z. H. (2015). The Effect of Realistic Mathematic Education on Students' Conceptual Understanding of Linear Progamming. Creative Education. https://doi.org/10.4236/ce.2015.622251

Ibáñez, M. B., \& Delgado-Kloos, C. (2018). Augmented reality for STEM learning: A systematic review. Computers and Education. https://doi.org/10.1016/j.compedu.2018.05.002

Iis Holisin. (2007). Pembelajaran Matematika Realistik (PMR). Didaktis.

Juniriang Zendrato. (2016). Tingkat Penerapan Rencana Pelaksanaan Pembelajaran dalam Pelaksanaan Pembelajaran di Kelas. Scholaria.

Kunandar. (2015). Penilaian Autentik (Penilaian Hasil Belajar Pesrta Didik Berdasarkan Kurikulum 2013. In Jurnal Evaluasi Pendidikan. https://doi.org/10.21009/JEP.022.05

Lample, G., \& Charton, F. (2019). Deep Learning For Symbolic Mathematics. ArXiv.

Lander, J. A., \& Brown, H. D. (1995). Teaching by Principles: An Interactive Approach to Language Pedagogy. Language. https://doi.org/10.2307/415773

Laurens, T., Batlolona, F. A., Batlolona, J. R., \& Leasa, M. (2018). How does realistic mathematics education (RME) improve students' mathematics cognitive achievement? Eurasia Journal of Mathematics, Science and Technology Education. https://doi.org/10.12973/ejmste/76959

Lestari, L., \& Surya, E. (2017). The Effectiveness of Realistic Mathematics Education Approach on Ability of Students ' Mathematical Concept Understanding. International Journal of Sciences: Basic and Applied Research (IJSBAR).

Makonye, J. P. (2014). Teaching Functions Using a Realistic Mathematics Education Approach: A Theoretical Perspective. International Journal of Educational Sciences. 
https://doi.org/10.1080/09751122.2014.11890228

Mattingly, C., Lutkehaus, N. C., \& Throop, C. J. (2008). Bruner's search for meaning: A conversation between psychology and anthropology. Ethos.

https://doi.org/10.1111/j.1548-1352.2008.00001.x

Milaturrahmah, N., Mardiyana, M., \& Pramudya, I. (2017). Mathematics Learning Process with Science, Technology, Engineering, Mathematics (STEM) Approach in Indonesia. Journal of Physics: Conference Series. https://doi.org/10.1088/1742-6596/895/1/012030

Miles, M. B., \& Huberman, M. A. (2012). Analisis Data Kualitatif: Buku Sumber Tentang Metode-Metode Baru. In Universitas Indonesia_UI Press.

Muhtadi, D., \& Sukirwan, S. (2018). Implementasi Pendidikan Matematika Realistik (Pmr) Untuk Meningkatkan Kemampuan Berpikir Kreatif Matematik Dan Kemandirian Belajar Peserta Didik. Mosharafa: Jurnal Pendidikan Matematika. https://doi.org/10.31980/mosharafa.v6i1.289

Nasution, A. (2014). Perencanaan Pengajaran. Darul Ilmi.

Navilarekallu, T. (2020). Classroom. Resonance. https://doi.org/10.1007/s12045-020-0941-y

Nesari, A. J., \& Heidari, M. (2014). The Important Role of Lesson Plan on Educational Achievement of Iranian EFL Teachers' Attitudes. International Journal of Foreign Language Teaching \& Research.

Nida, T. (2019). A lesson plan model for character education in primary education. Educational Research and Reviews. https://doi.org/10.5897/err2018.3616

Oftiana, S., \& Saefudin, A. A. (2017). Pengaruh Pendekatan Pembelajaran Matematika Realistik Indonesia (Pmri) Terhadap Kemampuan Pemecahan Masalah Matematika Siswa Kelas VII SMP Negeri 2 Srandakan. MaPan. https://doi.org/10.24252/mapan.v5n2a10

Partners for 21st Century Skills. (2006). 21st Century Skills Map. Classroom21.Ncdpi.Wikispaces.Net.

Prastiti, T. (2009). Implementasi Realistic Mathematics Education Dengan Memperhatikan Gaya Kognitif Siswa Dan Pengaruhnya Terhadap Kemampuan Komunikasi Dan Pemecahan Masalah Matematika SMP. Jurnal Pendidikan Dan Pembelajaran Universitas Negeri Malang.

Ragbir-Shripat, D., \& Mohan, P. (2019). A methodology for incorporating creativity into lesson plans. 14th International Conference on Computer Science and Education, ICCSE 2019. https://doi.org/10.1109/ICCSE.2019.8845323

Rahman, A. A. (2017). Penerapan Pendekatan Realistic Mathematic Education ( Rme ) Pada Materi Statistika Untuk Meningkatkan Pemahaman Konsep Dan Prestasi. Genta Mulia.

Rashad Ali Bin-Hady, W., \& Abdulsafi, A. S. T. (2019). How Can I Prepare an Ideal Lesson-Plan? SSRN Electronic Journal. https://doi.org/10.2139/ssrn.3434031

Ridder, H. G., Miles, M. B., Michael Huberman, A., \& Saldaña, J. (2014). Qualitative data analysis. A methods sourcebook. Zeitschrift Fur Personalforschung. https://doi.org/10.1177/239700221402800402

Soedjadi, R. (2014). Inti Dasar - Dasar Pendidikan Matematika Realistik Indonesia. Jurnal Pendidikan Matematika. https://doi.org/10.22342/jpm.1.2.807.

Strayer, J. F. (2012). How learning in an inverted classroom influences cooperation, innovation and task orientation. Learning Environments Research. https://doi.org/10.1007/s10984-012-9108-4

Sufiati, V., \& Afifah, S. N. (2019). Peran perencanaan pembelajaran untuk performance mengajar guru pendidikan anak usia dini. Jurnal Pendidikan Anak. https://doi.org/10.21831/jpa.v8i1.26609

Susilowati, E. (2018). Peningkatan Aktivitas dan Hasil Belajar Matematika Siswa SD Melalui Model Realistic Mathematic Education (RME) Pada Siswa Kelas IV Semester I Di SD Negeri 4 Kradenan Kecamatan Kradenan Kabupaten Grobogan Tahun Pelajaran 2017/2018. PINUS: Jurnal Penelitian Inovasi Pembelajaran. https://doi.org/10.29407/pn.v4i1.12494

Tarigan, D. E. (2012). Analisis Kemampuan Pemecahan Masalah Matematika Berdasarkan Langkah-Langkah Polya Pada Materi Sistem Persamaan Linear Dua Variabel Bagi Siswa Kelas VIII SMP NEGERI 9 Surakarta Ditinjau Dari Kemampuan Penalaran Siswa.

Tarigan, D., \& Sinaga, E. M. (2015). Perbedaan Hasil Belajar Siswa Dalam Pendekatan Realistik Dengan Pendekatan Ekspositori Pada Mata Pelajaran Matematika Kelas IV SDN 101880 Tanjung Morawa. Kreano, Jurnal Matematika Kreatif-Inovatif. https://doi.org/10.15294/kreano.v6i1.4473

Ulandari, L., Amry, Z., \& Saragih, S. (2019). Development of Learning Materials Based on Realistic Mathematics Education Approach to Improve Students' Mathematical Problem Solving Ability and Self-Efficacy. International Electronic Journal of Mathematics Education. https://doi.org/10.29333/iejme/5721

Vaccari, A., Farias, G. F., \& Porto, D. S. (2020). Implementation of a lesson plan model in the nursing laboratory: strengthening learning. Revista Gaucha de Enfermagem. https://doi.org/10.1590/19831447.2020.20190174

Van den Heuvel-Panhuizen, M., \& Drijvers, P. (2014). Realistic Mathematics Education. In Encyclopedia of Mathematics Education. https://doi.org/10.1007/978-94007-4978-8_170

Vidal, R., Bruna, J., Giryes, R., \& Soatto, S. (2017). Mathematics of deep learning. ArXiv.

Wardono, Waluya, S. B., Mariani, S., \& Candra, S. D. (2016). Mathematics Literacy on Problem Based Learning with Indonesian Realistic Mathematics Education Approach Assisted E-Learning Edmodo. Journal of Physics: Conference Series. https://doi.org/10.1088/17426596/693/1/012014

Wibowo, A. (2017). Pengaruh pendekatan pembelajaran matematika realistik dan saintifik terhadap prestasi belajar, kemampuan penalaran matematis dan minat belajar. Jurnal 
Riset Pendidikan Matematika. https://doi.org/10.21831/jrpm.v4i1.10066

Widada, W., Nugroho, K. U. Z., Sari, W. P., \& Pambudi, G. A. (2019). The ability of mathematical representation through realistic mathematics learning based on ethnomathematics. Journal of Physics: Conference Series. https://doi.org/10.1088/1742-6596/1318/1/012073

Widyastuti, N. S., \& Pujiastuti, P. (2014). Pengaruh Pendidikan Matematika Realistik Indonesia (Pmri) Terhadap Pemahaman Konsep Dan Berpikir Logis SiswA. Jurnal Prima Edukasia. https://doi.org/10.21831/jpe.v2i2.2718

Wijaya, A. (2012). Pendidikan matematika realistik. In Yogyakarta: Graha Ilmu.

Wismath, S. L. (2013). Shifting the Teacher-Learner Paradigm: Teaching for the 21st Century. College Teaching. https://doi.org/10.1080/87567555.2012.752338

Zakaria, E., \& Syamaun, M. (2017). The Effect of Realistic Mathematics Education Approach on Students' Achievement And Attitudes Towards Mathematics. Mathematics Education Trends and Research. https://doi.org/10.5899/2017/metr-00093 